\title{
Novel antigens in non-small cell lung cancer: SP17, AKAP4, and PTTG1 are potential immunotherapeutic targets
}

\author{
Leonardo Mirandola ${ }^{1,2}$, Jose A. Figueroa ${ }^{1,3}$, Tam T. Phan ${ }^{1}$, Fabio Grizzi ${ }^{4}$, Minji \\ Kim $^{1}$, Rakhshanda Layeequr Rahman ${ }^{5}$, Marjorie R. Jenkins ${ }^{1,2}$, Everardo $\operatorname{Cobos}^{1,2,3}$, \\ Cynthia Jumper ${ }^{6}$, Raed Alalawi' ${ }^{6}$ and Maurizio Chiriva-Internati ${ }^{1,2,3}$ \\ ${ }^{1}$ Division of Hematology \& Oncology and Southwest Cancer Treatment and Research Center, Texas Tech University, Lubbock, \\ TX, USA \\ ${ }^{2}$ Laura W. Bush Institute for Women's Health and Center for Women's Health and Gender-Based Medicine, Amarillo, TX, USA \\ ${ }^{3}$ Kiromic, LLC. Lubbock, TX, USA \\ ${ }^{4}$ Humanitas Clinical and Research Center, Milano, Italy \\ ${ }^{5}$ Division of Surgical Oncology, Texas Tech University Medical Center, Amarillo, TX, USA \\ ${ }^{6}$ Division of Pulmonary and Critical Care Medicine, Department of Internal Medicine, Texas Tech University Health Sciences \\ Center, Lubbock, TX, USA
}

Correspondence to: Maurizio Chiriva-Internati, email: m.chirivainternati@gmail.com

Keywords: cancer/testis antigens, lung cancer, cancer vaccines

Received: September 29, $2014 \quad$ Accepted: November 15,2014Ｐublished: November 162014

This is an open-access article distributed under the terms of the Creative Commons Attribution License, which permits unrestricted use, distribution, and reproduction in any medium, provided the original author and source are credited.

\section{ABSTRACT}

Lung cancer is the leading cause of cancer deaths in both genders worldwide, with an incidence only second to prostate cancer in men and breast cancer in women. The lethality of the disease highlights the urgent need for innovative therapeutic options. Immunotherapy can afford efficient and specific targeting of tumor cells, improving efficacy and reducing the side effects of current therapies. We have previously reported the aberrant expression of cancer/testis antigens (CTAs) in tumors of unrelated histological origin. In this study we investigated the expression and immunogenicity of the CTAs, Sperm Protein 17 (SP17), A-kinase anchor protein 4 (AKAP4) and Pituitary Tumor Transforming Gene 1 (PTTG1) in human non-small cell lung cancer (NSCLC) cell lines and primary tumors. We found that SP17, AKAP4 and PTTG1 are aberrantly expressed in cancer samples, compared to normal lung cell lines and tissues. We established the immunogenicity of these CTAs by measuring CTA-specific autoantibodies in patients' sera and generating CTA-specific autologous cytotoxic lymphocytes from patients' peripheral blood mononuclear cells. Our results provide proof of principle that the CTAs SP17/AKAP4/PTTG1 are expressed in both human NSCLC cell lines and primary tumors and can elicit an immunogenic response in lung cancer patients.

\section{INTRODUCTION}

Lung cancer is the leading cause of cancer-related deaths worldwide, with approximately 226,160 new cases and 160,340 deaths in the Unites States in 2013[1]. Non-small cell lung carcinoma (NSCLC) accounts for approximately $85 \%$ of diagnosed lung cancers and is associated with an overall 5-year survival rate of less than $20 \%[1]$. Despite advances in the diagnosis and treatment of patients with NSCLC, the vast majority of patients succumb to the disease. Therefore, there is an urgent need to develop more effective therapies for patients suffering from this devastating neoplasm.

Immunotherapy has recently emerged as a promising therapy for NSCLC[2]. The generation of immune responses against specific tumor-associated antigens and/ or manipulation of T-cell checkpoints to enhance antitumor responses are an active area of investigation[2]. Cancer/testis antigens (CTAs) are a family of proteins with testis-restricted expression and negligible expression 
in normal tissues. We and others have shown that CTAs are frequently expressed in many tumors at the mRNA and protein levels [3-6]. More recently, the CTAs NY-ESO-1 and MAGE-A2/3/4/6 have been detected in NSCLC primary tumors and their immunogenicity suggests they are promising targets for the development of potentially effective lung cancer vaccines [7-9]. We have previously demonstrated that the CTAs SP17, AKAP4, Ropporin, and PTTG1 are potential immunotherapeutic targets in ovarian cancer, multiple myeloma, and prostate cancer $[3,10-12]$. In this study we evaluated RNA and protein expression patterns of SP17, AKAP4 and PTTG1 in NSCLC cell lines and primary tumor samples from NSCLC patients, compared to normal lung cells and tissues. We also determined the immunogenicity of these CTAs by measuring CTA-specific antibodies (Abs) in the sera of lung cancer patients and generating CTA-specific cytotoxic anti-tumor responses in vitro, using autologous peripheral blood mononuclear cells (PBMCs).

\section{RESULTS}

\section{SP17/AKAP4/PTTG1 mRNAs are up-regulated in NSCLC primary tumors compared to normal lung tissues}

SP17, AKAP4 and PTTG1 expression was determined by qRT-PCR in a panel of cDNAs from NSCLC and normal lung tissues. Figure 1 shows that SP17, AKAP4, and PTTG1 were undetectable in normal lung samples, with the exception of AKAP4 in 1 healthy sample which showed weak expression. Overall, more than $65 \%(n=26)$ of NSCLC showed the expression of at least one CTA, while more than $20 \%(n=8)$ expressed 2 or more. Forty percent of samples were SP17+, 25\% were AKAP4 $4^{+}$, while $20 \%$ were PTTG $1^{+}$. There was no association with tumor histological type, grade, or stage.

\section{SP17/AKAP4/PTTG1 protein expression is} present in NSCLC cell lines and primary tumor specimens, but not in normal bronchus epithelium

We explored CTA expression in 2 NSCLC cell lines and 1 immortalized normal bronchus cell line. ICC analysis (Figure 2) shows undetectable expression of the CTA panel in the normal bronchus cell line (CRL-2503), whereas the 3 CTAs were detected in NSCLC cell lines (CRL-5928 and CRL-5922).

We then validated the specificity of CTA protein expression in normal and primary NSCLC tissues using IF and flow-cytometry. IF (Figure 3) shows that SP17, AKAP4 and PTTG1 are expressed by NSCLC cell lines, but not by the CRL-2503 non-tumorigenic bronchial cell line. Figure 3 also shows representative results from 3 patients (results for all of the patients evaluated in this study are summarized in Table 2). Flow-cytometry (Figure 4) confirmed these results, showing that SP17, AKAP4 and PTTG1 are expressed by NSCLC cell lines, but not by the non-transformed bronchial cell line. Figure 4 also shows representative results from 3 patients. The specificity of CTA expression in NSCLC was confirmed by the absence of positive staining for all CTAs in tissue derived from
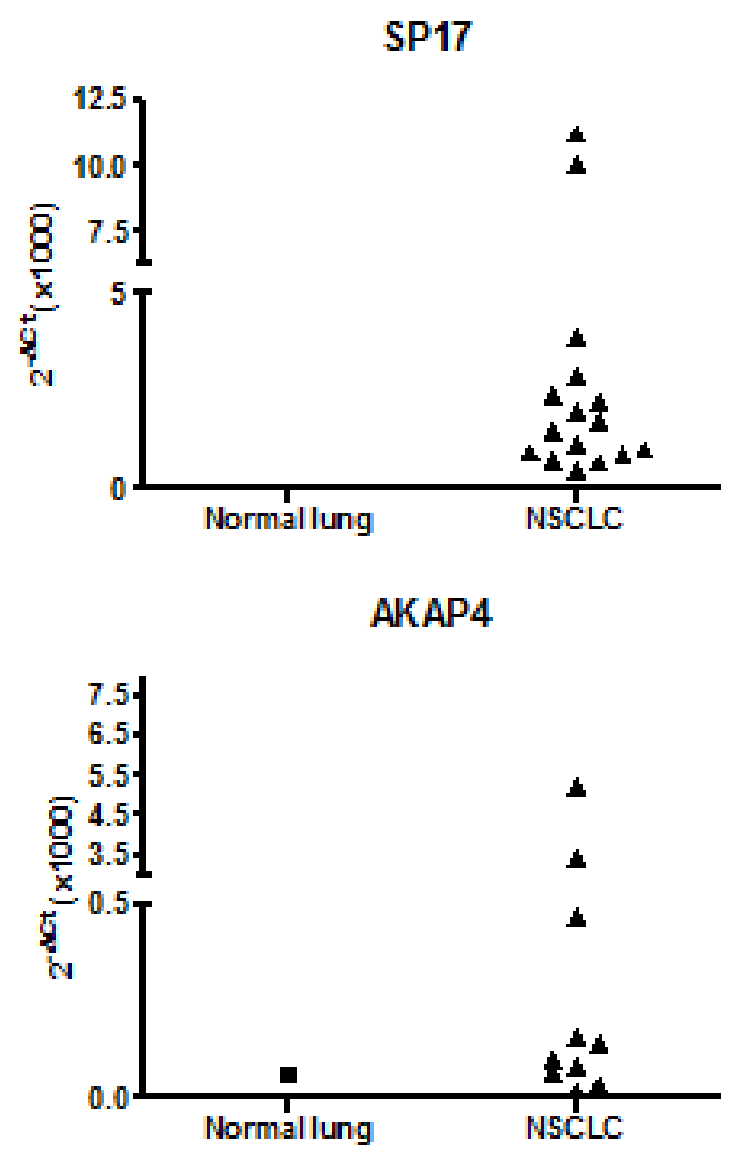

PTTG1

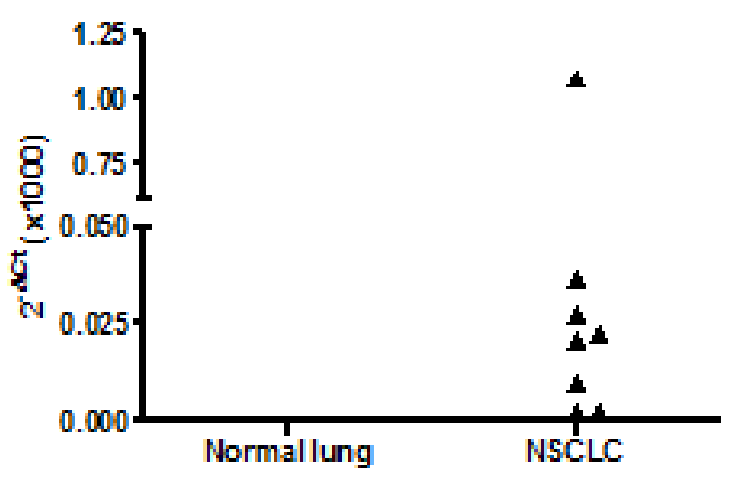

Figure 1: qRT-PCR analysis of CTA expression in cohort 1. Data are expressed as means calculated out of assays run in triplicate. $\beta$-actin was used as internal reference to compute the $\delta \mathrm{Ct}$ values. 


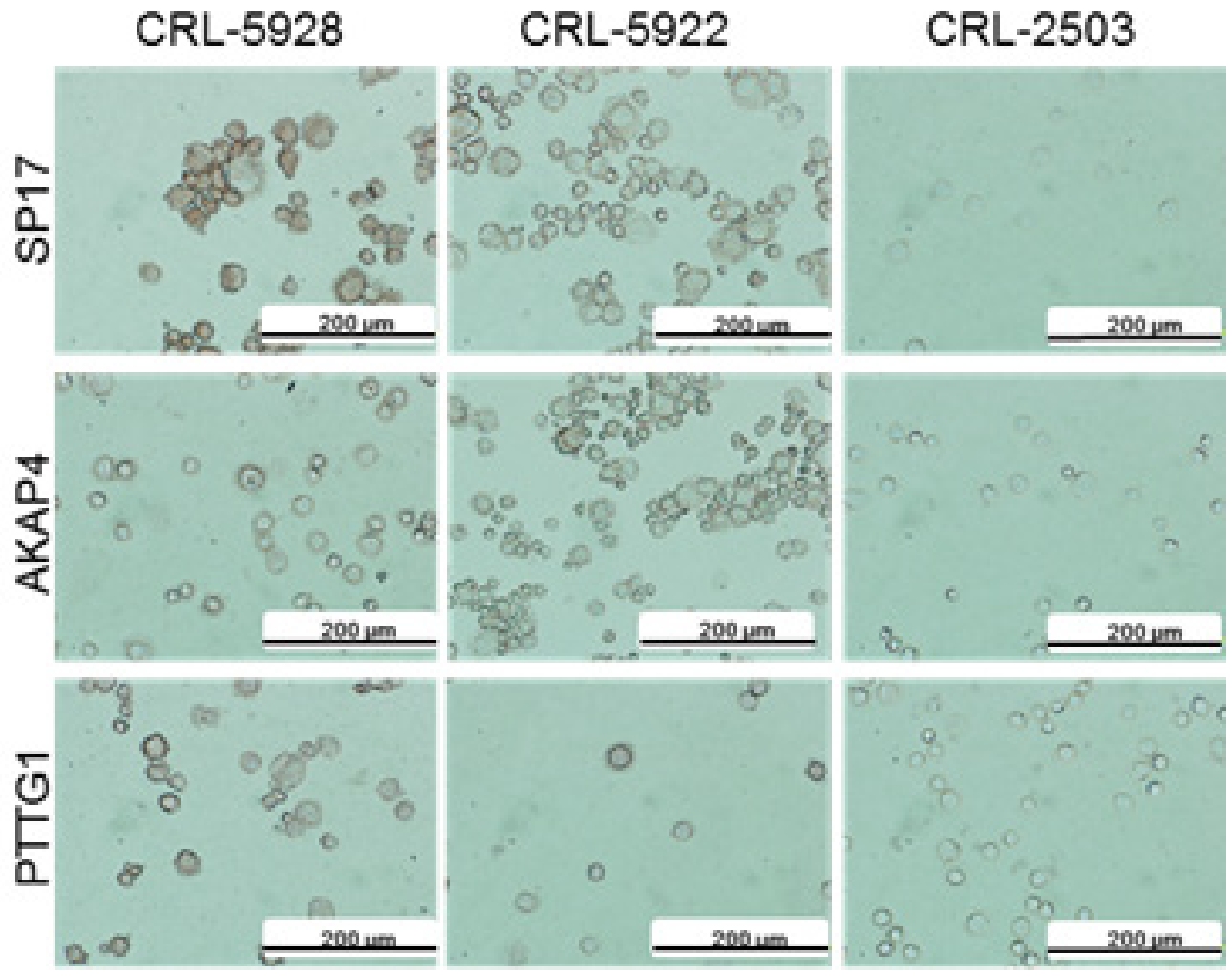

Figure 2: Immunocytochemistry. NSCLC cell lines and the non-tumor bronchus epithelium cell line, CRL-2503, were analyzed for CTA expression using DAB staining (brown signal). pictures were taken using an inverted Olympus X71 microscope.

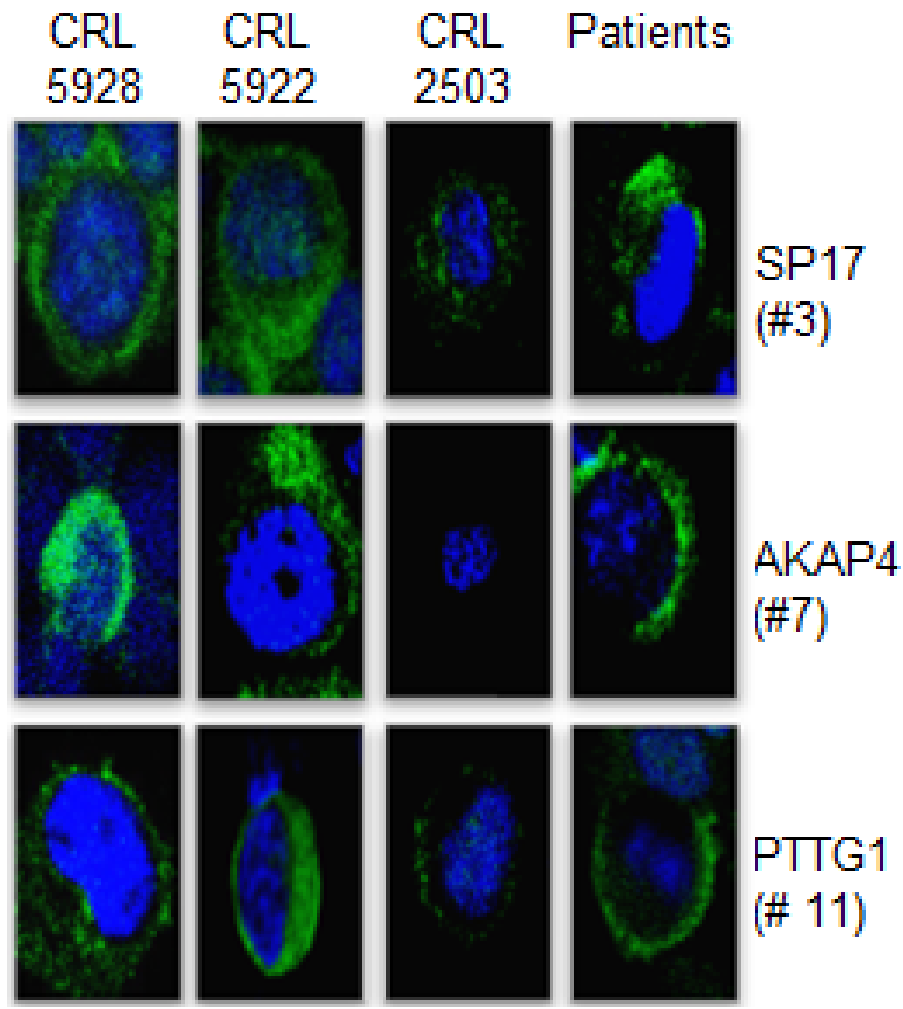

Figure 3: Immunofluorescence. Representative IF performed on NSCLC cell lines, CRL-5928, CRL-5922, on the normal bronchus epithelium-derived cells CRL-2503, and representative patients. We show the positive stain for SP17/AKAP4/PTTG1 (green signal) in the cytoplasm. Blue signal (nucleus) = DAPI. Pictures were taken at $60 \mathrm{X}$ magnification by an inverted florescence microscope (Olympus IX71). 
Table 1: Characteristics of the samples evaluated by qRT-PCR. + or - indicates the PCR was positive or negative for the indicated CTA (SP17, AKAP4, or PTTG1). +/-= weak expression.

\begin{tabular}{|c|c|c|c|c|c|c|}
\hline Histology (stage) & $\operatorname{sex}$ & age & Stage & SP17 & AKAP4 & PTTG1 \\
\hline $\begin{array}{l}\text { Within normal } \\
\text { limits }\end{array}$ & Male & 64 & $\mathrm{n} / \mathrm{a}$ & - & - & - \\
\hline $\begin{array}{l}\text { Within normal } \\
\text { limits }\end{array}$ & Female & 49 & $\mathrm{n} / \mathrm{a}$ & - & $+/-$ & - \\
\hline $\begin{array}{l}\text { Within normal } \\
\text { limits }\end{array}$ & Male & 79 & $\mathrm{n} / \mathrm{a}$ & - & - & - \\
\hline $\begin{array}{l}\text { Within normal } \\
\text { limits }\end{array}$ & Female & 70 & $\mathrm{n} / \mathrm{a}$ & - & - & - \\
\hline $\begin{array}{l}\text { Within normal } \\
\text { limits }\end{array}$ & Female & 62 & $\mathrm{n} / \mathrm{a}$ & - & - & - \\
\hline $\begin{array}{l}\text { Within normal } \\
\text { limits }\end{array}$ & Male & 49 & $\mathrm{n} / \mathrm{a}$ & - & - & - \\
\hline $\begin{array}{l}\text { Within normal } \\
\text { limits }\end{array}$ & Male & 70 & $\mathrm{n} / \mathrm{a}$ & - & - & - \\
\hline $\begin{array}{l}\text { Within normal } \\
\text { limits }\end{array}$ & Male & 72 & $\mathrm{n} / \mathrm{a}$ & + & - & - \\
\hline $\begin{array}{c}\text { Carcinoma of } \\
\text { lung, squamous } \\
\text { cell }\end{array}$ & Female & 75 & IA & - & - & - \\
\hline $\begin{array}{l}\text { Tumor of lung, } \\
\text { carcinoid }\end{array}$ & Female & 72 & IA & + & - & - \\
\hline $\begin{array}{l}\text { Carcinoma of } \\
\text { lung, squamous } \\
\text { cell }\end{array}$ & Male & 71 & IA & - & - & + \\
\hline $\begin{array}{c}\text { Carcinoma of } \\
\text { lung, } \\
\text { adenosquamous }\end{array}$ & Male & 66 & IA & - & - & - \\
\hline $\begin{array}{l}\text { Carcinoma of } \\
\text { lung, squamous } \\
\text { cell }\end{array}$ & Male & 79 & IB & + & - & - \\
\hline $\begin{array}{l}\text { Carcinoma of } \\
\text { lung, large cell }\end{array}$ & Male & 79 & $\mathrm{IB}$ & + & - & + \\
\hline $\begin{array}{c}\text { Carcinoma of } \\
\text { lung, } \\
\text { adenosquamous }\end{array}$ & Female & 68 & IB & + & - & - \\
\hline $\begin{array}{c}\text { Adenocarcinoma } \\
\text { of lung }\end{array}$ & Male & 64 & IB & - & + & - \\
\hline $\begin{array}{l}\text { Carcinoma of } \\
\text { lung, non-small } \\
\text { cell }\end{array}$ & Male & 65 & IB & + & + & - \\
\hline $\begin{array}{l}\text { Carcinoma of } \\
\text { lung, non-small } \\
\text { cell }\end{array}$ & Female & 70 & IB & - & - & - \\
\hline $\begin{array}{l}\text { Carcinoma of } \\
\text { lung, large cell }\end{array}$ & Male & 81 & IB & + & - & - \\
\hline
\end{tabular}




\begin{tabular}{|c|c|c|c|c|c|c|}
\hline $\begin{array}{c}\text { Carcinoma of } \\
\text { lung, squamous } \\
\text { cell }\end{array}$ & Female & 85 & IB & - & - & - \\
\hline $\begin{array}{l}\text { Carcinoma of } \\
\text { lung, squamous } \\
\text { cell }\end{array}$ & Male & 76 & IB & - & - & - \\
\hline $\begin{array}{l}\text { Carcinoma of } \\
\text { lung, sarcomatoid }\end{array}$ & Female & 66 & IB & + & + & - \\
\hline $\begin{array}{l}\text { Carcinoma of } \\
\text { lung, non-small } \\
\text { cell }\end{array}$ & Male & 71 & IB & - & - & - \\
\hline $\begin{array}{c}\text { Carcinoma of } \\
\text { lung, squamous } \\
\text { cell }\end{array}$ & Male & 66 & IB & + & - & - \\
\hline $\begin{array}{c}\text { Adenocarcinoma } \\
\text { of lung }\end{array}$ & Female & 62 & IB & + & - & - \\
\hline $\begin{array}{l}\text { Carcinoma of } \\
\text { lung, squamous } \\
\text { cell }\end{array}$ & Male & 72 & IB & - & - & - \\
\hline $\begin{array}{l}\text { Adenocarcinoma } \\
\text { of lung }\end{array}$ & Female & 64 & IB & - & - & - \\
\hline $\begin{array}{l}\text { Carcinoma of } \\
\text { lung, large cell }\end{array}$ & Male & 66 & IB & + & + & - \\
\hline $\begin{array}{l}\text { Carcinoma of } \\
\text { lung, large cell, } \\
\text { neuroendocrine }\end{array}$ & Male & 58 & IIA & - & - & - \\
\hline $\begin{array}{c}\text { Carcinoma of } \\
\text { lung, squamous } \\
\text { cell }\end{array}$ & Female & 68 & IIA & - & + & + \\
\hline $\begin{array}{l}\text { Carcinoma of } \\
\text { lung, non-small } \\
\text { cell }\end{array}$ & Male & 63 & IIB & - & - & - \\
\hline $\begin{array}{l}\text { Carcinoma of } \\
\text { lung, squamous } \\
\text { cell }\end{array}$ & Male & 77 & IIB & + & - & - \\
\hline $\begin{array}{l}\text { Adenocarcinoma } \\
\text { of lung }\end{array}$ & Female & 55 & IIB & + & + & + \\
\hline $\begin{array}{l}\text { Adenocarcinoma } \\
\text { of lung, acinar, } \\
\text { papillary }\end{array}$ & Female & 77 & IIB & - & - & - \\
\hline $\begin{array}{l}\text { Carcinoma of } \\
\text { lung, large cell, } \\
\text { neuroendocrine }\end{array}$ & Male & 62 & IIB & - & + & - \\
\hline $\begin{array}{c}\text { Adenocarcinoma } \\
\text { of lung }\end{array}$ & Female & 71 & IIB & - & - & + \\
\hline $\begin{array}{c}\text { Carcinoma of } \\
\text { lung, squamous } \\
\text { cell }\end{array}$ & Male & 71 & IIB & - & + & - \\
\hline $\begin{array}{l}\text { Carcinoma of } \\
\text { lung, squamous } \\
\text { cell }\end{array}$ & Male & 76 & IIB & - & + & + \\
\hline $\begin{array}{l}\text { Adenocarcinoma } \\
\text { of lung }\end{array}$ & Male & 81 & IIB & - & + & - \\
\hline
\end{tabular}




\begin{tabular}{|c|c|c|c|c|c|c|}
\hline $\begin{array}{l}\text { Carcinoma of } \\
\text { lung, squamous } \\
\text { cell }\end{array}$ & Female & 66 & IIB & + & - & - \\
\hline $\begin{array}{l}\text { Carcinoma of } \\
\text { lung, large cell }\end{array}$ & Male & 72 & IIB & - & - & + \\
\hline $\begin{array}{c}\text { Adenocarcinoma } \\
\text { of lung, } \\
\text { bronchioloalveolar }\end{array}$ & Female & 38 & IIB & - & - & - \\
\hline $\begin{array}{l}\text { Carcinoma of } \\
\text { lung, squamous } \\
\text { cell }\end{array}$ & Male & 58 & IIIA & + & - & + \\
\hline $\begin{array}{l}\text { Carcinoma of } \\
\text { lung, squamous } \\
\text { cell }\end{array}$ & Male & 62 & IIIA & - & + & - \\
\hline $\begin{array}{l}\text { Adenocarcinoma } \\
\text { of lung, papillary }\end{array}$ & Male & 66 & IIIA & + & - & - \\
\hline $\begin{array}{c}\text { Adenocarcinoma } \\
\text { of lung }\end{array}$ & Male & 80 & IIIB & - & - & - \\
\hline $\begin{array}{l}\text { Carcinoma of } \\
\text { lung, squamous } \\
\text { cell }\end{array}$ & Male & 57 & IIIB & - & - & - \\
\hline $\begin{array}{l}\text { Carcinoma of } \\
\text { lung, non-small } \\
\text { cell, metastatic }\end{array}$ & Male & 51 & IV & - & + & - \\
\hline
\end{tabular}

a healthy individual (a representative result is displayed in Figure 4). Table 2 summarizes the results obtained on the NSCLC cohort. Overall, $52 \%$ of samples were SP17+, $29 \%$ were $\mathrm{AKAP}^{+}$, while $35 \%$ were $\mathrm{PTTG}^{+}$.

\section{Circulating CTA-specific autoantibodies are detectable in the sera of NSCLC patients}

We compared the levels of circulating CTA-specific IgG autoantibodies in sera from NSCLC patients with those from healthy subjects, by indirect ELISA. A subject was considered positive if the ELISA signal was at least 2 Standard Deviations (SD) higher than the median signal found in healthy subjects [13]. Figure 5 shows that the majority of NSCLC patients displayed CTA-specific autoantibodies. Detailed results for each patient are summarized in Table 2.

\section{Generation of CTA-specific CTLs from patients' PBMCs}

We generated CTLs from 5 patients displaying SP17, AKAP4 and PTTG1 protein expression and demonstrated specific lysis of autologous tumor cells and CTA-expressing cell lines (Figure 6). CTL lysis of NSCLC cells derived from patient samples was observed at different effector/target cell ratios (Figure 6, left panel). CTA specificity of CTL-dependent NSCLC cell lysis was confirmed when NSCLC cells were exposed to CTLs generated using non-pulsed DCs and DCs pulsed with HPV-E7 antigen (Figure 6, right panel). HLA class I restriction was evidenced by the inhibition of cytotoxic effect with HLA-I blocking antibody, but not HLA-II blockade (Figure 6, right). Th1 polarization was demonstrated after stimulation with CTA-pulsed DCs and co-culture with tumor cells, by detecting more than 50 -fold increase in IFN- $\gamma$ and TNF- $\alpha$ production and no significant change in IL-4, IL-5, and IL-10 levels, using ELISA (Figure 7, left panel). The ELISPOT for IFN- $\gamma$ further confirmed the increased in IFN- $\gamma$-producing cells derived from PBMCs activated with CTA- presenting DCs, and co-cultured with tumor cells (Figure 7, right panel).

\section{DISCUSSION}

Although NSCLC has historically been considered a weakly immunogenic malignancy[8,] several studies have shown it is possible to generate an effective immune response using a DC-based approach $[14,15]$. Furthermore, tumor-specific T-cells have been detected in patients with NSCLC [15], indicating identification of specific NSCLC-associated antigens, and presentation to the immune system in an optimal fashion may generate tumor-specific CTLs against this disease $[16,17]$. The potential role of immunotherapy in NSCLC patients has been demonstrated by a recent meta-analysis of 12 clinical vaccine trials [17]. When developing cancer immunotherapy, ideal targets for this approach should elicit strong immunogenicity and demonstrate selective expression in cancer cells, but not in normal tissues 

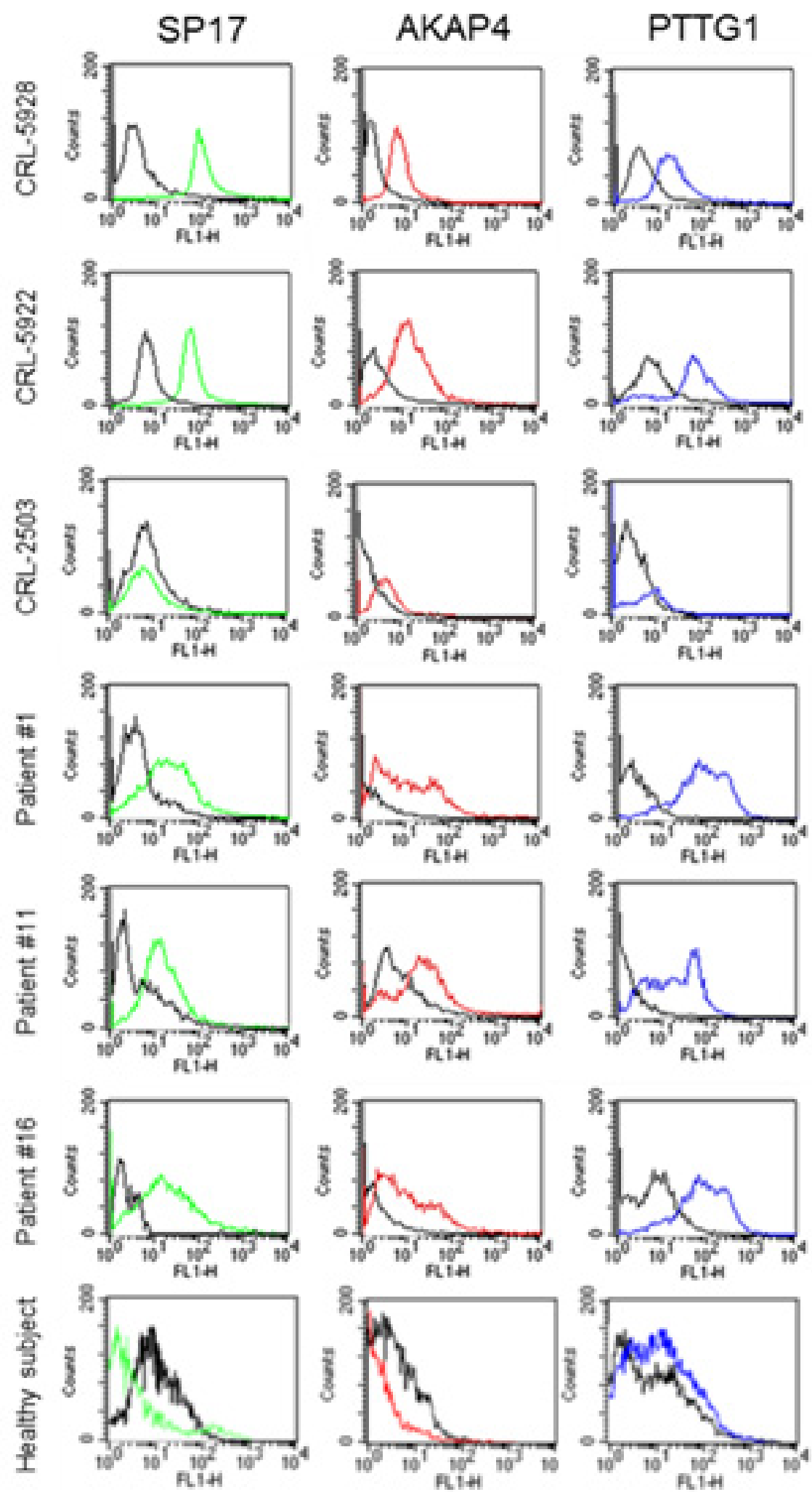

Figure 4: Flow-cytometry analysis. Cells were incubated with the indicated antibody (colored histograms) or corresponding isotypic controls (black histograms). Fluorescence intensity was measured on FSC/SSC-gated cells (10,000 events) using a FACS-Canto flow cytometer (BD). 
Table 2: Characteristics of the NSCLC patient's cohort evaluated by FC, IF, and ELISA. + or - indicates the tumor cells were positive or negative for the indicated CTA (SP17, AKAP4, or PTTG1), or for the CTA-specific IgG (n.a.= serum not available).

\begin{tabular}{|c|c|c|c|c|c|c|c|c|c|}
\hline Histology (stage) & sex & age & $\begin{array}{c}\text { smoke } \\
\text { history? }\end{array}$ & SP17 & AKAP4 & PTTG1 & $\begin{array}{l}\text { SP17- } \\
\text { IgG }\end{array}$ & $\begin{array}{l}\text { AKAP4- } \\
\text { IgG }\end{array}$ & $\begin{array}{l}\text { PTTG1- } \\
\text { IgG }\end{array}$ \\
\hline $\begin{array}{l}\text { Squamous cell } \\
\text { carcinoma (IIIA) }\end{array}$ & $F$ & 79 & yes & - & - & + & - & - & + \\
\hline Adenocarcinoma & M & 74 & no & - & - & + & - & - & + \\
\hline $\begin{array}{l}\text { Squamous cell } \\
\text { carcinoma (IV) }\end{array}$ & $M$ & 76 & no & + & - & - & + & - & - \\
\hline $\begin{array}{c}\text { Large cell } \\
\text { carcinoma NOS }\end{array}$ & $M$ & 49 & yes & + & - & + & + & - & + \\
\hline $\begin{array}{l}\text { Adenocarcinoma } \\
\text { (II) }\end{array}$ & $\mathrm{M}$ & 58 & yes & + & - & - & + & - & - \\
\hline $\begin{array}{l}\text { Non-small cell } \\
\text { carcinoma (I) }\end{array}$ & $M$ & 67 & yes & + & - & - & + & - & - \\
\hline $\begin{array}{c}\text { Adenocarcinoma } \\
\text { (IIIA) }\end{array}$ & $M$ & 65 & yes & - & + & + & - & + & + \\
\hline Carcinoma (IIIA) & $\mathrm{F}$ & 75 & yes & + & + & - & n.a. & n.a. & n.a. \\
\hline $\begin{array}{l}\text { Squamous cell } \\
\text { carcinoma (II) }\end{array}$ & $F$ & 71 & yes & + & + & - & + & + & - \\
\hline $\begin{array}{l}\text { Adenocarcinoma } \\
\text { (IIIB) }\end{array}$ & $F$ & 59 & yes & + & - & + & + & - & + \\
\hline $\begin{array}{c}\text { Adenocarcinoma } \\
\text { (IV) }\end{array}$ & $M$ & 66 & no & - & - & + & - & - & + \\
\hline $\begin{array}{l}\text { Non-small cell } \\
\text { carcinoma (IIIB) }\end{array}$ & $F$ & 80 & yes & - & - & - & - & - & - \\
\hline $\begin{array}{l}\text { Squamous cell } \\
\text { carcinoma (IIIA) }\end{array}$ & $M$ & 58 & yes & - & + & - & - & + & - \\
\hline $\begin{array}{l}\text { Adenocarcinoma } \\
\text { (II) }\end{array}$ & $\mathrm{M}$ & 51 & yes & + & - & - & n.a. & n.a. & n.a. \\
\hline $\begin{array}{l}\text { Adenocarcinoma } \\
\text { (IIIB) }\end{array}$ & $\mathrm{M}$ & 50 & yes & - & + & - & - & + & - \\
\hline $\begin{array}{l}\text { Bronchiolo- } \\
\text { alveolar } \\
\text { carcinoma non- } \\
\text { mucinous (II) }\end{array}$ & $F$ & 70 & yes & + & - & - & n.a. & n.a. & n.a. \\
\hline $\begin{array}{c}\text { Adenocarcinoma } \\
\text { (IIIA) }\end{array}$ & $F$ & 64 & yes & - & - & - & - & - & - \\
\hline
\end{tabular}

[2]. CTAs are particularly attractive in this regard based on their tumor-restricted expression pattern and immunogenicity $[4,6]$, and indeed there is a considerable effort ongoing to develop high throughput techniques, such as bioinformatic meta-analyses [18], for the identification of novel CTAs that are likely clinically relevant as cancer biomarkers and immunotherapy targets.

Here we provide "proof-of principle" for the use of three CTAs, namely SP17, AKAP4, and PTTG1, in the development of NSCLC immunotherapy. We analyzed the differential expression of these CTAs in NSCLC primary tumors, NSCLC cell lines, in healthy lung epithelium samples and in one non-tumorigenic, normal bronchus cell line. NSCLC cell lines expressed
SP17/AKAP4/PTTG1 transcripts and proteins, while the non-tumorigenic cell line showed only weak SP17 and PTTG1 expression in immunofluorescence but was negative by immunocytochemistry, possibly due to the higher sensitivity of immunofluorescence. Although we are aware that the data on protein expression is limited to a normal bronchus cell line, this finding is consistent with our previous observations showing that SP17 is expressed in ciliated somatic epithelia, including those of the airways [19]. Moreover, the CRL-2503 is a bronchial epithelial cell line "immortalized" by transfection with the SV40 T antigen, a genetic alteration with unknown effects on SP17 expression. The expression of SP17 RNA by a non-neoplastic bronchial cell line raises the question 
of potential broncho-pulmonary toxicity when targeting this specific CTA. Nevertheless, preclinical studies using SP17-directed immunotherapies have not demonstrated any toxicity to ciliated cells $[11,20,21]$. Therefore, these observations indicate the level of SP17 expression in these
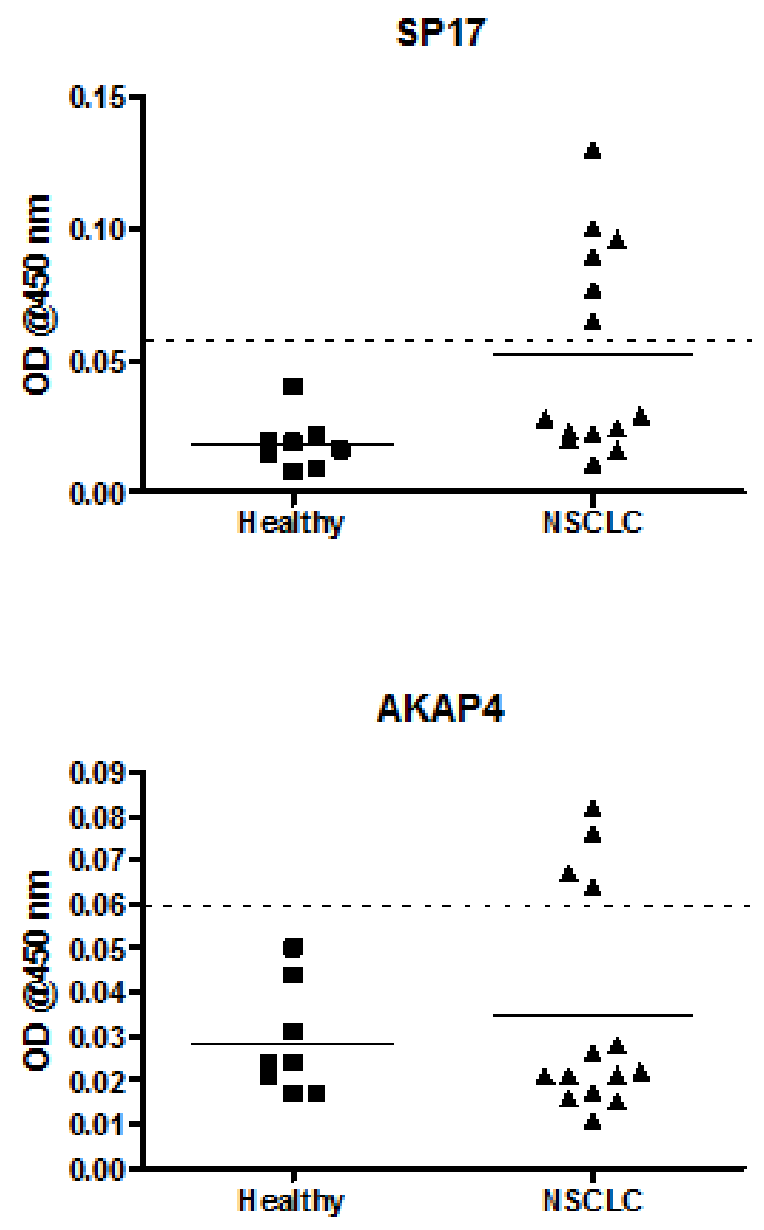

PTTG1

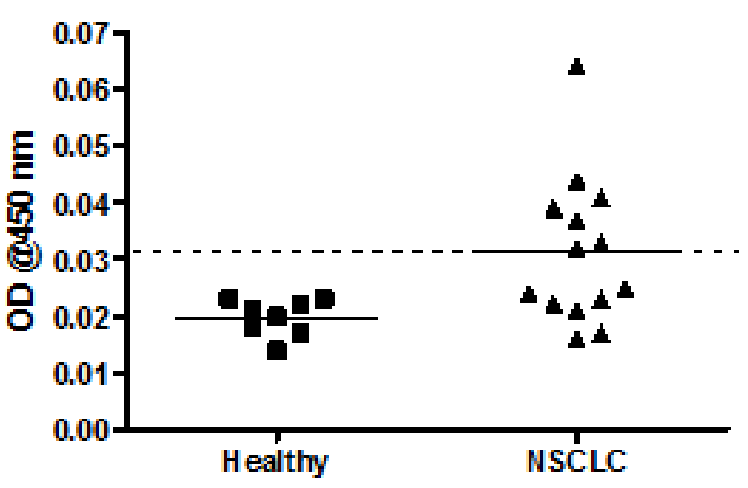

Figure 5: ELISA for the detection of circulating CTAspecific IgG. Graphs display mean OD values calculated from experiments run in triplicate. The horizontal dotted line represents the positivity cut-off, calculated as the median value obtained from the healthy control group +2 standard deviations. cells is not sufficient to elicit a cytotoxic response. We analyzed two cohorts of NSCLC and normal pulmonary bronchus: one ( $\mathrm{n}=48,40$ NSCLC samples, 8 normal lung) was commercially available (OriGene) and was analyzed by qRT-PCR, while the second cohort $(n=25,17$ NSCLC
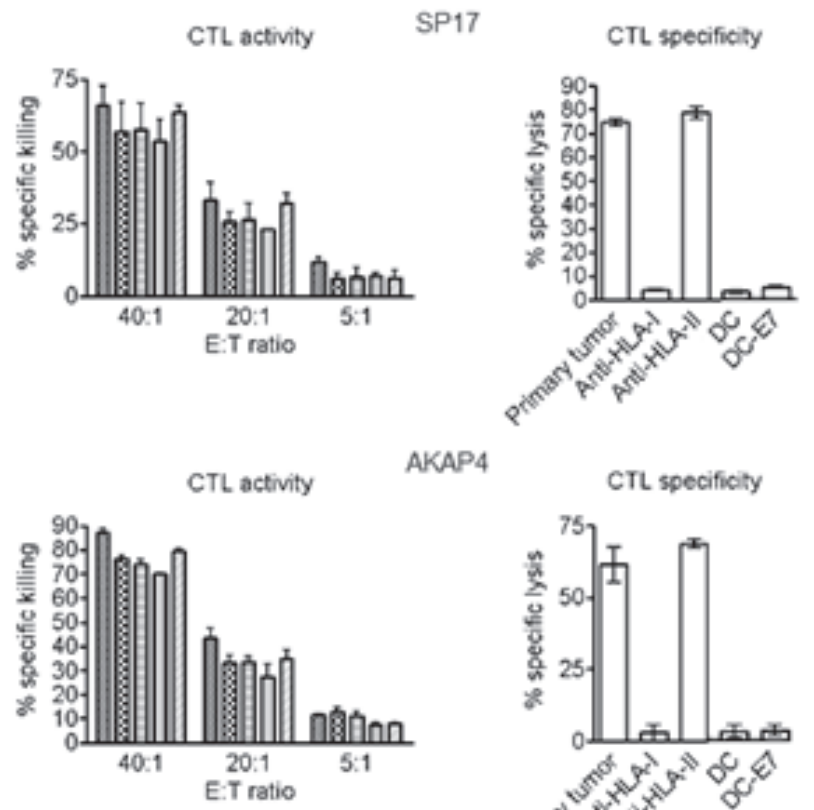

AKAP4
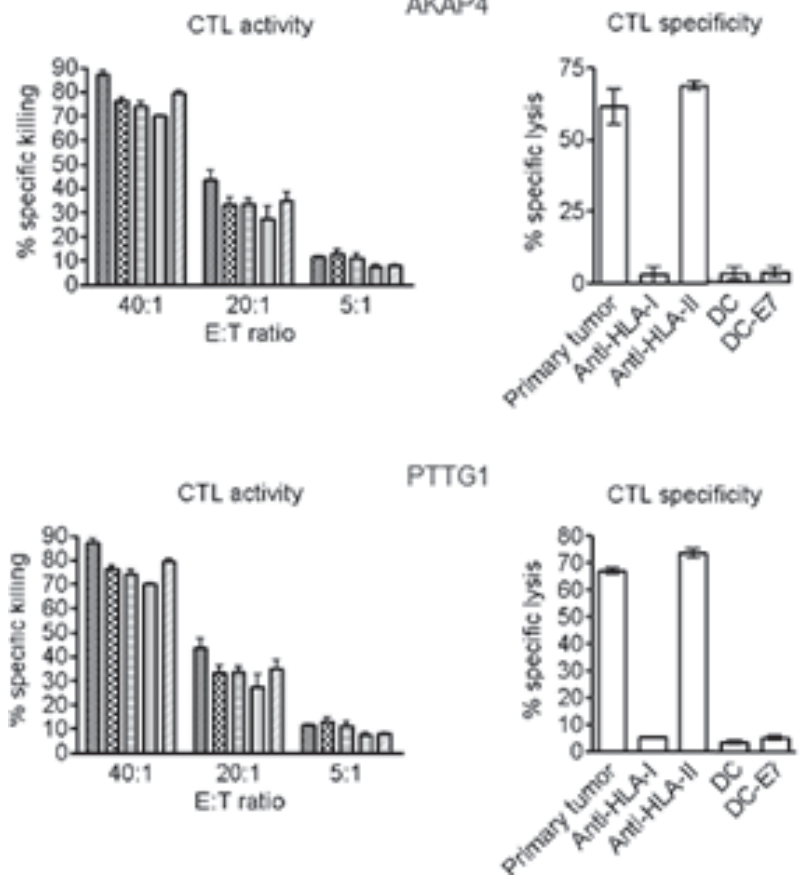

Figure 6: Analysis of CTL activity (left) and specificity (right). The histograms show the percentage of specific lysis obtained through a non-radioactive EUROPIUM-based assay under the indicated different conditions. The left panel shows the CTL activity at different ratios of effector (E, autologous $\mathrm{CTL}$ ): target ( $\mathrm{T}$, autologous primary tumor cells) cells. Bars represent the mean of experiments run in triplicate, and error bars represent standard deviations. The right panel shows the analysis of CTL specificity. Bars represent the mean values obtained from experiments run on the selected 5 patients, while error bars represent standard deviations. Antibodies against HLA class I (W6/32) and HLA class II (L243) were added (to block the MHC-I/CD8 and MHC-II/CD4 interaction respectively), at a concentration of $25 \mu \mathrm{g} / \mathrm{mL}$. Target specificity was confirmed by a lack of significant response against CTA-negative cells (DC not loaded with CTA or DC presenting the CTA-unrelated antigen, HPV-E7). CTL indicates cytotoxic T lymphocyte; DC, dendritic cell; HLA, human leukocyte antigen; E7, HPV-E7 antigen; PBMCs, peripheral blood mononucleated cell. 
samples and 8 normal lung) was analyzed by flowcytometry, immunofluorescence, and ELISA. Overall, qRT-PCR data and flow-cytometry/immunofluorescence analysis showed comparable CTA expression frequencies in tumor samples, while the CTAs were undetectable in normal lung samples. In the second cohort, CTA protein expression was confirmed independently by flowcytometry and immunofluorescence, with consistent results. Of note, more than $88 \%$ of tumors showed expression of at least one out of three CTAs studied, while 29\% expressed two CTAs, suggesting their relevance as potential therapeutic targets in this disease. Such broad expression could potentially be further expanded with pharmacological treatment based on de-methylating agents: Li B et al. [22] recently showed that CTAs expression can be induced in tumors showing low CTA positivity by 5-aza-2'-deoxycytidine. Of note, they correlated such CTA induction with specific CD8+ T-cell response against osteosarcoma in vitro and in vivo.

For a protein to serve as a target for immunotherapy it must elicit a measurable, vigorous and durable immune response. We found NSCLC patient sera contained CTA-specific antibodies, suggesting SP17, AKAP4, and PTTG1 were markedly immunogenic in patients with this disease. Conversely, none of the healthy individuals, or patients whose tumors didn't express CTAs, were found to have circulating anti-CTA antibodies. Shan et al. [23] have also reported anti-NY-ESO-1, XAGE-1, ADAM29
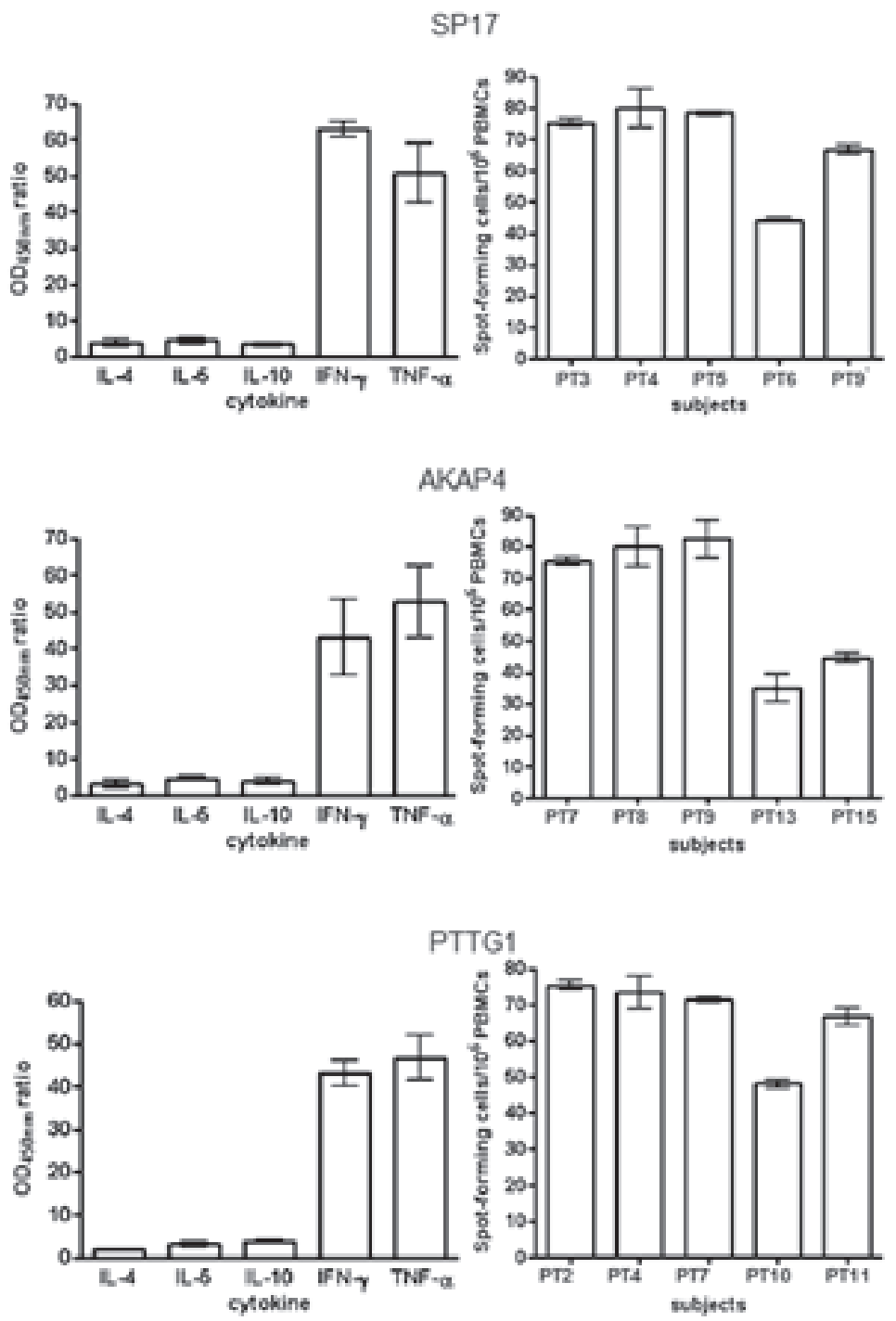

Figure 7: ELISA and ELISPOT. Left panel: supernatants from co-cultures (20:1 effector: target ratio) of autologous tumor cells and PBMCs stimulated with CTA-pulsed or unmodified DCs were analyzed for the levels of the indicated cytokines. All measurements were run in triplicate. Results are displayed as the mean ODs measured with activated PBMCs divided by the mean ODs obtained with PBMCs incubated with autologous DCs without antigens $\left(\mathrm{OD}_{450}\right.$ ratio). Right panel: IFN- $\gamma$ expression by patients' CTLs co-cultured with autologous tumor cells (20:1 effector:target ratio) was evaluated using ELISPOT assay as detailed in the Materials and Methods section. Spot counts were performed with an AID ELISPOT Reader System (Cell Technology, Inc., Columbia, MD) and normalized per 10 ${ }^{6}$ PBMCs. Results represent the means \pm standard deviations of assays run in triplicate. 
and MAGEC1 Abs in the serum of NSCLC patients, but not in healthy individuals. Thus, our findings suggest the potential utility of measuring anti-SP17/AKAP4/PTTG1 antibodies in patients' sera as a marker of immunogenicity against these antigens and, possibly, as a diagnostic tool in NSCLC patients. Since our results are based on a limited series of patients' samples, we believe further analysis is warranted to determine the prevalence and significance of the presence of circulating anti-CTA antibodies in this patient population. Spontaneous CTA-specific immune responses against tumor cells are a feature commonly seen in other malignancies such as recently found in estrogenreceptor negative breast cancers [24], and they might also have an outcome on patients' overall survival, as described by Freitas M, et al., who reported the expression of the CTAs, ACTL8, OIP5, XAGE3 and CTCFL, as an independent predictor of better OS in glioblastoma [25].

To determine if SP17/AKAP4/PTTG1 could trigger a tumor-specific cytotoxic response, we used CTAloaded DCs to generate CTLs [3, 5, 26, 27]. For each antigen, we selected patients that tested positive for SP17, AKAP4, and PTTG1 protein expression in tumor cells. As expected, patients' PBMCs stimulated with CTA-loaded DCs displayed significant lytic activity against autologous NSCLC cells. The observed cytotoxic effect was clearly HLA class I-restricted and CTA-specific. Cytokine expression analysis revealed that our DC-based CTL generation protocol induced a strong effector polarization in stimulated PBMCs, as evidenced by increased IFN- $\gamma$ and TNF- $\alpha$ levels, but no changes in tolerogenic IL-4, IL-5, and IL-10 production [3, 11, 27-29]. Since NSCLC patients have been shown to have an abnormal Th-2type cytokine pattern [30] which negatively impacts immunotherapy [31], we believe the ability of CTA-loaded DCs to stimulate Th-1 polarization effect may be clinically relevant [32]. The activation of effector CTLs was further demonstrated by IFN- $\gamma$ ELISPOT analysis. This finding is relevant since increased IFN- $\gamma$ by CTLs has been shown to exert significant inhibitory effects on NSCLC growth [33].

\section{CONCLUSIONS}

The feasibility of generating an active, CTAspecific immune response in vitro indicates the expression of the CTAs Sp17, AKAP-4 and PTTG1 by NSCLC cells could have therapeutic relevance and serve as the basis for designing novel immunotherapeutic strategies against this disease. We believe that DCs engineered in vitro to recognize and present specific CTAs, such as SP17, AKAP4 and PTTG1, may result in activation of Th1-polarized CTLs capable of overcoming the immunosuppression [31] seen in the NSCLC microenvironment. Therefore, a therapeutic strategy that targets these specific CTAs may result in the development of effective DC-based vaccines against NSCLC [34]. Further studies are necessary to determine the optimal way to generate CTA-specific CTL responses in vivo, in order to overcome the immune tolerance observed in this disease [35].

\section{MATERIALS AND METHODS}

\section{Cells lines}

The NSCLC cell lines CRL-5928 (squamous cell carcinoma), CRL-5922 (adenocarcinoma), and the immortalized, non-tumorigenic human bronchial epithelial cell line CRL-2503 (established by transfection with the origin of replication-defective SV40 large T plasmid), were obtained from the American Type Culture Collection (ATCC, Manassas, VA, USA) and maintained according to ATCC guidelines at $37^{\circ} \mathrm{C}$ and $5 \% \mathrm{CO}_{2}$.

\section{Patients and Clinical Materials}

We evaluated a total of 57 NSCLC samples and 16 non-tumor samples, as follows. For quantitative RT-PCR (qRT-PCR), we analyzed 40 NSCLC- and 8 normal lungderived cDNA samples obtained from OriGene (Table 1, cat. \# HLRT301, OriGene, Rockville, MD, USA). For flow-cytometry, ELISA, and cytotoxicity assay, we used 17 NSCLC biopsy samples (median patient's age = 66 years) derived from patients (Table 2) and 8 samples from healthy subjects (no history of smoking, median age $=59$ years, 5 females, 3 males) who underwent bronchial biopsy. Sera were collected at the time of routine blood tests as previously described[3]. Materials from human subjects were obtained with approval of the Texas Tech University HSC IRB (L-Micro Study, IRB NUMBER: L04-095), and the patients' written informed consent. Biopsies were minced and plated in RPMI-1640 supplemented with $10 \%$ FBS, $20 \mathrm{mM}$ HEPES buffer, $100 \mathrm{U} / \mathrm{mL}$ penicillin, $100 \mathrm{mg} / \mathrm{mL}$ streptomycin. Cells were maintained in $5 \% \mathrm{CO}_{2}$ and $37{ }^{\circ} \mathrm{C}$ for 16 hours prior to analysis.

\section{qRT-PCR}

qRT-PCR analysis was performed as previously described[3], using an iCycler iQ Real Time PCR machine SYBR ${ }^{\circ}$ Green I Supermix (both from BioRad Laboratories, Inc). The primers sequences were: SP17: 5'- GCTCGGAGAGAAAGGAGGTTC-3'; 5'- TACTCCCCCATTCTGCTGGA-3'; AKAP4: 5'- CAGTCAAGGCTGTAGGAGGG-3' and 5'- AGCATATCACTTTCCGGTCC-3'; PTTG1: 5'- AGTACTTGTTGGCTCACGCC-3' and 5'AGGAGACTGCAACAGATTGGA-3'; $\beta$-actin: 5'-CGT CTT CCC CTC CAT CG-3' and 5'-CTC GTT AAT GTC 
ACG CAC-3'. Values were expressed by the $2^{-\delta \mathrm{CCt}}$ formula, where $\Delta \mathrm{Ct}=\mathrm{Ct}$ housekeeping ( $\beta$-actin)-Ct gene.

\section{Immunocytochemistry (ICC)}

Following tryspinization for 5 minutes, cell lines were suspended in PBS and spun down on a microscope slide $(10,000 /$ spot $)$, then the fixed with $2 \%$ formaldehyde in PBS. The staining procedure was performed at room temperature using the same protocol for tissues and cell lines, as follows. Endogenous peroxidase blockade was performed in $0.3 \% \mathrm{~V} / \mathrm{V} \mathrm{H}_{2} \mathrm{O}_{2}$ for 5 minutes. Following permeabilization with $0.15 \% \mathrm{~V} / \mathrm{V}$ Triton-X100 in PBS, samples were rinsed in PBS and blocked with blocking buffer (5\% FBS $+0.05 \%$ Tween-20 in PBS) for 1 hour, then incubated with the primary antibody $(10 \mu \mathrm{g} / \mathrm{mL}$ in blocking buffer) for 1 hour. After 3 washing steps in blocking buffer (5 minutes each), samples were incubated with the corresponding secondary antibody $(2 \mu \mathrm{g} / \mathrm{mL}$ in blocking buffer) for 1 hour. HRP-DAB reaction was carried out for 5 minutes after 3 additional washes, and stopped in water. Slides were mounted with a glycerolbased medium before taking pictures with an inverted Olympus X71 microscope. Antibodies were as follows: rabbit anti-SP17 and mouse anti-PTTG1 (Abcam), goat anti-AKAP4 (Santa Cruz). All secondary antibodies (HRP-linked) were from Abcam.

\section{Flow-cytometry}

400,000 cells were washed with PBS $1 \mathrm{X}$ and fixed with buffered paraformaldehyde $(4 \% \mathrm{~W} / \mathrm{V}$ in PBS, $\mathrm{pH}=7.4$ ). After 5 -min permeabilization on ice with permeabilization buffer $(0.3 \% \mathrm{~V} / \mathrm{V}$ saponin in PBS), cells were incubated with specific primary Abs: rabbit anti-human SP17, goat anti-human AKAP4 (Santa Cruz Biotechnology, Santa Cruz, CA, USA), or rabbit antihuman PTTG1 (Novus Biologicals, CO, USA). Negative controls were cells incubated with equal amounts of isotype-matching unspecific IgG immunoglobulins (Novus Biologicals, LLC, Littleton, CO, USA). After 1-h incubation on ice, cells were washed three times in permeabilization buffer, and then incubated on ice (20 minutes) with the appropriate FITC-conjugated secondary antibody (BD Biosciences, CA, USA). Following 3 washing steps with permeabilization buffer, cells were resuspended in PBS and analyzed using a FACS-Canto flow cytometer (BD).

\section{Immunofluorescence}

Immunofluorescence was performed as previously described[12]. Briefly, 20,000 cells were subjected to cytospin and fixed with SlideRite (Fisher). Each sample was permeabilized in $0.1 \%$ Triton X-100 sodium citrate buffer for 15 minutes at $4{ }^{\circ} \mathrm{C}$. Cells were then incubated overnight at $4{ }^{\circ} \mathrm{C}$ with the specific primary antibodies as described in the flow-cytometry method $(1: 100$ dilution) and then with FITC-conjugated rabbit IgG secondary antibodies (1:500 dilution, Abcam). Standard DAPI staining was used to detect the nuclei. Staining was observed with an inverted fluorescence microscope (Olympus IX71), and representative images were captured at $60 \mathrm{X}$ and $10 \mathrm{X}$ magnification.

\section{ELISA for detection of CTA-specific antibodies}

Polystyrene 96-well plates were coated with recombinant proteins (SP17, AKAP4 or PTTG1, from Novus Biologicals, LLC, Littleton, CO, USA) in $50 \mu \mathrm{L}$ carbonate coating buffer $(10 \mu \mathrm{g} /$ well $)$ for 2 hours at 25 ${ }^{\circ} \mathrm{C}$. After washing twice with $100 \mu \mathrm{L}$ PBS, plates were blocked with $1 \% \mathrm{~W} / \mathrm{V}$ BSA in PBS for 1 hour. BSA was then removed and $50 \mu \mathrm{L}$ sera (diluted 1:5 in PBS) were added to plates. After 1 hour incubation at $34{ }^{\circ} \mathrm{C}$, plates were washed twice with $100 \mu \mathrm{L}$ washing buffer $(0.05 \%$ $\mathrm{V} / \mathrm{V}$ Tween-20 in PBS), and incubated with HRP-linked mouse anti-human IgG (Abcam, diluted 1:4,000 in PBS). After 1-hr incubation in the dark plates were washed twice with $100 \mu \mathrm{L}$ washing buffer and then incubated with HRP substrate solution (TMB) in the dark for 5 minutes at $22{ }^{\circ} \mathrm{C}$. Absorbance was read at $450 \mathrm{~nm}$ after incubation with $1 \mathrm{~N} \mathrm{HCl}$. Absorbance of negative controls (antigenfree wells incubated with commercial antibodies) was subtracted to that obtained in wells incubated with sera.

\section{Isolation of PBMCs and Generation of Dendritic Cells (DCs)}

Heparinized blood was centrifuged in a FicollHypaque gradient to separate PBMCs, which were then incubated in RPMI-1640 medium $\left(3 \times 10^{6}\right.$ cells $\left./ \mathrm{mL}\right)$ for 2 hours. Non-adherent cells were removed and adherent cells were cultured in complete RPMI-1640 supplemented with $1000 \mathrm{IU} / \mathrm{mL}$ IL-4 and $800 \mathrm{IU} / \mathrm{mL}$ GM-CSF. After 1 week, DCs were harvested and pulsed with human recombinant SP17, AKAP4 or PTTG1 as described [3].

\section{Pulsing}

DCs were washed twice and placed in a $50 \mathrm{~mL}$ polypropylene tube. Recombinant proteins were mixed with the cationic lipid DOTAP (Roche, Mannheim, Germany) for 20 minutes at RT, and added to the DCs for 3 hours at $37^{\circ} \mathrm{C}$. 


\section{Generation of CTA-specific Cytotoxic T Lymphocytes (CTLs), in vitro}

Antigen-pulsed DCs were co-cultured with fresh autologous PBMCs [3] at a ratio of 1:10 in RPMI-1640 supplemented with $10 \%$ autologous serum, $10 \mathrm{IU} / \mathrm{mL}$ $\mathrm{IL}-2$ and $5 \mathrm{ng} / \mathrm{mL} \mathrm{IL-7}$ at $37^{\circ} \mathrm{C}, 5 \% \mathrm{CO}_{2}$. Irradiated autologous PBMCs feeder cells and recombinant CTAs $(50 \mu \mathrm{g} / \mathrm{mL})$ were added once a week, and IL- 2 was added every 3 days. Recombinant CTAs were endotoxin-free, as confirmed by endotoxin detection assay performed through the ToxinSensor Chromogenic LAL Endotoxin Assay Kit (GenScript USA Inc., NJ).

\section{Cytotoxicity essay}

We performed an EUROPIUM-based cytotoxicity assay using the DELFIA ${ }^{\circledR}$ EuTDA system according to the manufacturer's instructions. Target cells were autologous tumor cells (at the effector-target cell ratios of 40:1, 20:1, or 5:1). Antibodies against HLA class I (W6/32) and HLA class II (L243) were added ( $25 \mu \mathrm{g} / \mathrm{mL})$ to evaluate HLA restricted cytotoxicity, with a fixed 20:1 (effector:target) ratio. Experiments were run in triplicates.

\section{ELISA}

ELISA was performed on the supernatants of activated PBMCs and autologous tumor cells 4-hour co-cultures (20:1 effector:target ratio). The U-CyTech sandwich ELISA kit (U-CyTech, Utrecht, The Netherlands) was used in accordance with the manufacturer's instructions. Reactions were developed by adding the TMB substrate and stopped by the addition of $2 \mathrm{M} \mathrm{H}_{2} \mathrm{SO}_{4}$. The absorbance was read at $450 \mathrm{~nm}$. Data are presented as the optical densities (ODs) measured with activated PBMCs divided by the ODs obtained with PBMCs incubated with autologous DCs without antigens (OD ratio).

\section{ELISPOT}

IFN- $\gamma$ expression was evaluated using ELISPOT assay (UCyTech, Utrecht, The Netherlands), as previously described [3]. Spots were counted with an AID ELISPOT Reader System (Cell Technology, Inc., Columbia, MD).

\section{Author Contributions}

Experimental design: MCI, LM, JAF, EC, CJ, MJ. Performed the experiments: LM, MK, TTP. Analysis of data: MCI, FB, LM, TTP, RA, JAF. Manuscript preparation: LM, MCI, EC, FG, RA, JAF, MJ, CJ, RLR. Guarantor of the paper: MCI.

\section{ACKNOWLEDGEMENTS}

The authors also thank Teri Fields for her assistance in editing this paper.

\section{Disclosures}

M.C.I. is the Chief Scientist and Founder of Kiromic, LLC. E.C. and J.A.F are the President and Chief Medical Officer of Kiromic, LLC, respectively. The remaining authors have no financial conflicts of interest. The sponsors did not have any role in designing the research, analyzing or commenting the results.

\section{Conflicts of interest}

M.C.I. is the Chief Scientist and Founder of Kiromic, LLC. E.C and J.A.F are the President and Chief Medical Officer of Kiromic, LLC, respectively. The remaining authors have no financial conflicts of interest.

\section{Funding information}

This work was supported in part by the Associate Dean for Oncology Programs at TTUHSC, The Billy and Ruby Power Endowment for Cancer Research, the Laura W. Bush Institute for Women's Health, Kiromic LLC and Endowed Chair for Excellence in Women's Health Director of Breast Health Service.

\section{Prior abstract publication/presentation}

This work was partially presented in abstract form at "New Antigens in Non-small Cell Lung Cancer Detected Both in Serology and Tissue", CHEST 2011 Annual Meeting, October 22-26 2011, Honolulu, Hawaii, USA.

\section{REFERENCES}

1. Siegel R, Naishadham D and Jemal A. Cancer statistics, 2012. CA Cancer J Clin. 2012; 62(1):10-29.

2. Mellman I, Coukos G and Dranoff G. Cancer 
immunotherapy comes of age. Nature. 2011; 480(7378):480-489.

3. Chiriva-Internati M, Yu Y, Mirandola L, D'Cunha N, Hardwicke F, Cannon MJ, Cobos E and Kast WM. Identification of AKAP-4 as a new cancer/testis antigen for detection and immunotherapy of prostate cancer. The Prostate. 2012; 72(1):12-23.

4. Caballero OL and Chen YT. Cancer/testis (CT) antigens: potential targets for immunotherapy. Cancer science. 2009; 100(11):2014-2021.

5. Mirandola L, M JC, Cobos E, Bernardini G, Jenkins MR, Kast WM and Chiriva-Internati M. Cancer testis antigens: novel biomarkers and targetable proteins for ovarian cancer. International reviews of immunology. 2011; 30(2-3):127137.

6. Mathieu MG, Miles AK, Li G, McArdle SE and Rees RC. Cancer/testis antigens for therapeutic use. Journal of BUON : official journal of the Balkan Union of Oncology. 2009; 14 Suppl 1:S97-102.

7. Bhan S, Negi SS, Shao C, Glazer CA, Chuang A, Gaykalova DA, Sun W, Sidransky D, Ha PK and Califano JA. BORIS binding to the promoters of cancer testis antigens, MAGEA2, MAGEA3, and MAGEA4, is associated with their transcriptional activation in lung cancer. Clinical cancer research : an official journal of the American Association for Cancer Research. 2011; 17(13):4267-4276.

8. Kim SH, Lee S, Lee CH, Lee MK, Kim YD, Shin DH, Choi KU, Kim JY, Park do Y and Sol MY. Expression of cancertestis antigens MAGE-A3/6 and NY-ESO-1 in non-smallcell lung carcinomas and their relationship with immune cell infiltration. Lung. 2009; 187(6):401-411.

9. Rao M, Chinnasamy N, Hong JA, Zhang Y, Zhang M, Xi S, Liu F, Marquez VE, Morgan RA and Schrump DS. Inhibition of histone lysine methylation enhances cancertestis antigen expression in lung cancer cells: implications for adoptive immunotherapy of cancer. Cancer research. 2011; 71(12):4192-4204.

10. Chiriva-Internati M, Mirandola L, Yu Y, Jenkins MR, Gornati R, Bernardini G, Gioia M, Chiaramonte R, Cannon MJ, Kast WM and Cobos E. Cancer testis antigen, ropporin, is a potential target for multiple myeloma immunotherapy. Journal of immunotherapy (Hagerstown, Md : 1997). 2011; 34(6):490-499.

11. Chiriva-Internati M, Yu Y, Mirandola L, Jenkins MR, Chapman C, Cannon M, Cobos E and Kast WM. Cancer testis antigen vaccination affords long-term protection in a murine model of ovarian cancer. PloS one. 2010; 5(5):e10471.

12. Chiriva-Internati M, Ferrari R, Prabhakar M, Yu Y, Baggoni L, Moreno J, Gagliano N, Portinaro N, Jenkins MR, Frezza EE, Hardwicke F, D'Cunha N, Kast W and Cobos E. The pituitary tumor transforming gene 1 (PTTG$1)$ : an immunological target for multiple myeloma. Journal of translational medicine. 2008; 6:15.
13. Santin AD, Bellone S, Palmieri M, Zanolini A, Ravaggi A, Siegel ER, Roman JJ, Pecorelli S and Cannon MJ. Human papillomavirus type 16 and 18 E7-pulsed dendritic cell vaccination of stage IB or IIA cervical cancer patients: a phase I escalating-dose trial. Journal of virology. 2008; 82(4):1968-1979.

14. Miller PW, Sharma S, Stolina M, Butterfield LH, Luo J, Lin Y, Dohadwala M, Batra RK, Wu L, Economou JS and Dubinett SM. Intratumoral administration of adenoviral interleukin 7 gene-modified dendritic cells augments specific antitumor immunity and achieves tumor eradication. Human gene therapy. 2000; 11(1):53-65.

15. Yasumoto $\mathrm{K}$, Hanagiri $\mathrm{T}$ and Takenoyama $\mathrm{M}$. Lung cancer-associated tumor antigens and the present status of immunotherapy against non-small-cell lung cancer. General thoracic and cardiovascular surgery. 2009; 57(9):449-457.

16. Raez LE, Fein $\mathrm{S}$ and Podack ER. Lung cancer immunotherapy. Clinical medicine \& research. 2005; 3(4):221-228.

17. Wang J, Zou ZH, Xia HL, He JX, Zhong NS and Tao AL. Strengths and weaknesses of immunotherapy for advanced non-small-cell lung cancer: a meta-analysis of 12 randomized controlled trials. PloS one. 2012; 7(3):e32695.

18. Sammut SJ, Feichtinger J, Stuart N, Wakeman JA, Larcombe L, McFarlane RJ. A novel cohort of cancer-testis biomarker genes revealed through meta-analysis of clinical data sets. Oncoscience. 2014; 1(5):349-359.

19. Grizzi F, Chiriva-Internati M, Franceschini B, Bumm K, Colombo P, Ciccarelli M, Donetti E, Gagliano N, Hermonat PL, Bright RK, Gioia M, Dioguardi N and Kast WM. Sperm protein 17 is expressed in human somatic ciliated epithelia. The journal of histochemistry and cytochemistry : official journal of the Histochemistry Society. 2004; 52(4):549-554.

20. Song JX, Cao WL, Li FQ, Shi LN and Jia X. AntiSp17 monoclonal antibody with antibody-dependent cell-mediated cytotoxicity and complement-dependent cytotoxicity activities against human ovarian cancer cells. Medical oncology (Northwood, London, England). 2012; 29(4):2923-2931.

21. Dadabayev AR, Wang Z, Zhang Y, Zhang J, Robinson WR and Lim SH. Cancer immunotherapy targeting Sp17: when should the laboratory findings be translated to the clinics? American journal of hematology. 2005; 80(1):6-11.

22. Li B, Zhu X, Sun L, Yuan L, Zhang J, Li H and Ye Z. Induction of a specific CD8+ T-cell response to cancer/ testis antigens by demethylating pre-treatment against osteosarcoma. Oncotarget. 2014.

23. Shan Q, Lou X, Xiao T, Zhang J, Sun H, Gao Y, Cheng S, $\mathrm{Wu} \mathrm{L}, \mathrm{Xu} \mathrm{N}$ and Liu S. A cancer/testis antigen microarray to screen autoantibody biomarkers of non-small cell lung cancer. Cancer letters. 2013; 328(1):160-167.

24. Caballero OL, Shousha S, Zhao Q, Simpson AJG, Charles Coombes RC, Munro Neville A. Expression of Cancer/ Testis genes in ductal carcinoma in situ and benign lesions 
of the breast. Oncoscience 2014, 1(1):14-20.

25. Freitas M, Malheiros S, Stavale JN, Biassi TP, Zamuner FT, de Souza Begnami M, Soares FA and Vettore AL. Expression of cancer/testis antigens is correlated with improved survival in glioblastoma. Oncotarget. 2013; 4(4):636-646.

26. Santin AD, Hermonat PL, Ravaggi A, Chiriva-Internati M, Zhan D, Pecorelli S, Parham GP and Cannon MJ. Induction of human papillomavirus-specific CD4(+) and CD8(+) lymphocytes by E7-pulsed autologous dendritic cells in patients with human papillomavirus type 16- and 18-positive cervical cancer. Journal of virology. 1999; 73(7):5402-5410.

27. Chiriva-Internati M, Wang Z, Salati E, Wroblewski D and Lim SH. Successful generation of sperm protein 17 (Sp17)specific cytotoxic T lymphocytes from normal donors: implication for tumour-specific adoptive immunotherapy following allogeneic stem cell transplantation for Sp17positive multiple myeloma. Scandinavian journal of immunology. 2002; 56(4):429-433.

28. Chiriva-Internati M, Wang Z, Salati E, Bumm K, Barlogie $\mathrm{B}$ and Lim SH. Sperm protein 17 (Sp17) is a suitable target for immunotherapy of multiple myeloma. Blood. 2002; 100(3):961-965.

29. Chiriva-Internati M, Liu Y, Weidanz JA, Grizzi F, You H, Zhou W, Bumm K, Barlogie B, Mehta JL and Hermonat PL. Testing recombinant adeno-associated virus-gene loading of dendritic cells for generating potent cytotoxic $\mathrm{T}$ lymphocytes against a prototype self-antigen, multiple myeloma HM1.24. Blood. 2003; 102(9):3100-3107.

30. Asselin-Paturel C, Echchakir H, Carayol G, Gay F, Opolon P, Grunenwald D, Chouaib S and Mami-Chouaib F. Quantitative analysis of Th1, Th2 and TGF-beta1 cytokine expression in tumor, TIL and PBL of non-small cell lung cancer patients. International journal of cancer Journal international du cancer. 1998; 77(1):7-12.

31. Ortegel JW, Staren ED, Faber LP, Warren WH and Braun DP. Modulation of tumor-infiltrating lymphocyte cytolytic activity against human non-small cell lung cancer. Lung cancer (Amsterdam, Netherlands). 2002; 36(1):17-25.

32. Bremnes RM, Al-Shibli K, Donnem T, Sirera R, Al-Saad S, Andersen S, Stenvold H, Camps C and Busund LT. The role of tumor-infiltrating immune cells and chronic inflammation at the tumor site on cancer development, progression, and prognosis: emphasis on non-small cell lung cancer. Journal of thoracic oncology : official publication of the International Association for the Study of Lung Cancer. 2011; 6(4):824-833.

33. Chen J, Hou J, Zhang J, An Y, Zhang X, Yue L, Liu J and Li X. Atorvastatin synergizes with IFN-gamma in treating human non-small cell lung carcinomas via potent inhibition of RhoA activity. European journal of pharmacology. 2012; 682(1-3):161-170.

34. Dubinett $\mathrm{S}$ and Sharma S. Towards effective immunotherapy for lung cancer: simultaneous targeting of tumor-initiating cells and immune pathways in the tumor microenvironment. Immunotherapy. 2009; 1(5):721-725.

35. Sautes-Fridman C, Dieu-Nosjean MC, Damotte D, Fisson S and Fridman WH. The immune microenvironments of lung and intraocular tumors. Bulletin du cancer. 2011; 98(6):5861. 